Relations industrielles

Industrial Relations

\title{
Toward Better Technical Words in the Trades
}

The Experience of a Parity Board and an Apprenticeship

Commission

\section{Léonce Girard}

Volume 5, numéro 9, juin 1950

URI : https://id.erudit.org/iderudit/1023406ar

DOI : https://doi.org/10.7202/1023406ar

Aller au sommaire du numéro

Éditeur(s)

Département des relations industrielles de l’Université Laval

ISSN

0034-379X (imprimé)

1703-8138 (numérique)

Découvrir la revue

Citer cet article

Girard, L. (1950). Toward Better Technical Words in the Trades: The Experience of a Parity Board and an Apprenticeship Commission. Relations industrielles /

Industrial Relations, 5(9), 81-83. https://doi.org/10.7202/1023406ar

Tous droits réservés @ C Département des relations industrielles de l’Université Laval, 1950
Ce document est protégé par la loi sur le droit d'auteur. L'utilisation des services d'Érudit (y compris la reproduction) est assujettie à sa politique d'utilisation que vous pouvez consulter en ligne.

https://apropos.erudit.org/fr/usagers/politique-dutilisation/ 


\section{Industrial Relations Bulletin}

Volume 5, number 9

QUEBEC

June 1950

\section{TOWARD BETTER TECHNICAL WORDS IN THE TRADES}

The experience of a parity board and an apprenticeship commission

Leonce Girard

You don't have to wrap yourself in a multitude of difficult and complicated principles when you get interested in social questions. But still there are certain simple and fundamental facts which should not be forgotten. Among others there is the following: when the state gives individuals the means to do something, they themselves regulate the problems of their profession fully as well as, if not better than, the public authorities could.

Since the Industrial Relations Bulletin grants me the occasion, I shall try to demonstrate the validity of this principle by applying it to one of the biggest problems in the trades and professions, the improvement of the technical language, especially the French terms and phrases in the trades. In the space of five years the parity board and the apprenticeship commission in the shoe industry have carried out a reform of truly national import, not only in giving the industry a French terminology, but also in getting it accepted gradually by a considerable number of employers and employees.

If a similar problem presents itself in your industry, and if you believe that the employees of our province ought to speak about their trade in precise terms rather than in a jargon of half English and half French, you will undoubtedly wish to know something of this experience and even, perhaps, to try the same thing in your own territory.

\section{The problem}

The members of the parity board, called upon to draw up the decree, and the representatives of the apprenticeship commission, charged with the job of teaching the trade to the new men, soon found out that a lot of the terms used in the shoe industry were, not just improper, but simply frightful. And what's more, the same problem is found in many other industries.

The machinery, the tools, the catalogues, come to us mostly from the United States. So the people in the industry learn first the English terms and then use them in speaking French. Thus the pattern maker "fait son 'standard" " or "son 'spider web" "; the cutter "découpe des 'vamp'", "des 'back strap'”, “des 'quarter'”, “des 'overlay'”; "l'homme de 'stock' 'channelle' la fausse"; the mounter "trimme l'inseam"; the borer "sluggue le 'top piece" "; and in the finishing department "on fait le 'burnishage'". The most elementary pride of profession cried out for the trade to improve its technical language.

\section{The committee}

A committee was set up to find trade terms and compile a list of them: official English terms and the corresponding French. The committee worked hard. The job wasn't easy. The French terms were so different from the English ones that when they read the French books they didn't understand them.

Finally, after comparing machines, designs, photographs, books, documents, the committee drew up, first of all, a list which was approved by the assembly, and then a mimeographed brochure of 36 pages with illustrations.

Here are some examples of parallel English and French expressions:

$$
\begin{aligned}
& \text { rough rounding - graver sur forme } \\
& \text { channelling insole - graver la première } \\
& \text { laying sole - ficher la semelle } \\
& \text { slugging heel - bonbouter le talon } \\
& \text { trimming edge - fraiser la lisse } \\
& \text { fixing wedge heel - poser le talon cambrure } \\
& \text { cutting back strap - tailler la baguette } \\
& \text { burnishing heel - lustrer le talon } \\
& \text { skiving vamp - parer l'empeigne }
\end{aligned}
$$

The names of the members of this committee will probably not go down in history; it is none the less true that they have rendered an immense service to the French language in the province.

\section{Diffusion}

To get to know these terms was the first step. But how get them adopted by the mass? A parity 
board and an apprenticeship commission always have means at their disposal, precisely because they enjoy the paramount advantage of immediate and daily contacts with employers and workmen in the industry.

All these contacts were pressed into service. First of all the terms were inserted in the decree; each operation was described with the terms decided upon, English and French. Then the inspectors of the parity board, who interviewed each wage-earner individually at least every three months, taught each French speaking employee the French term for his job. The "'trimmer' de lisses" learned that his job was called "fraiser la lisse"; the "rounder" found out that his work was called "graver sur forme"; the pattern maker made a "gabarit" instead of a "standard" and the cutter cut out "empeignes", "quartiers", "baguettes", and "appliqués".

Several manufacturers asked for the French terms and had their price lists printed in English and in French, so that now the piece worker can read the two terms each time he detaches a pay coupon.

For its part the apprenticeship commission uses the French terms in drawing up its courses and analysing the operations. The instructors of the school are directed to use the French terms so that when the apprentices leave the school they will be workers for the shoe industry who are familiar with these terms.

The apprenticeship commission went further. It gave abridged courses to every group of ten or fifteen employees who asked fur one, in the shoe trade schools, in factories, in workers' unions, throughout the province. The instructor, with shoe parts in hand, explained the parts and each operation, giving the exact French expressions.

And we received unexpected help. Some foremen, interested in the cause, each day wrote the French names of some operations on the blackboard in their departments, to make sure that each employee would learn them and use them.

Let us mention also that the "Information Service" sent to all manufacturers and wageearners in the industry complete lists of the principal French and English terms for each department, accompanied with illustrations. French or English terms, according to the case, are used in each bulletin.

Here, to sum up, are the means used by the parity board and the apprenticeship commission to popularize the French terms, and even the correct English ones, in the industry:
1. The parity board:

- revision and correction of the decree;

- interviews by the inspectors with each employee;

- revision of price lists or pay coupons;

- home propaganda by the "Information Service".

2. The apprenticeship commission:

- courses drawn up in French;

- terms taught by instructors in the school;

- abridged courses in the factories and union organizations;

- cooperation of foremen, personnel directors, and labour leaders.

Confidentially, is there any public authority which can use so many means at the same time to achieve these ends? For to do this it is necessary to know the industry in its details, as well as all the people who compose its personnel. The solving of the problems of a profession or trade belongs first of all to the employers and workmen of the industry; the job of the State is, not to substitute itself for the interested parties, but to second their efforts, as it has done, for instance, by the Collective Agreement Act and by the Apprenticeship Assistance Act.

\section{Results obtained}

Everything is not perfect yet; far from it. But progress continues and the technical language improves constantly. We have proofs of it every day. For instance we receive letters from manufacturers or their representatives, from labour organizations, or from foremen, which contain exclusively French terms in place of the expressions formerly current. More, translation bureaus ask us for the French terms. Tanners, manufacturers, dealers, not only in the province of Quebec, but in Ontario and the United States, make sure that their advertisements carry the French terms of the trade beside the correct English expressions.

All this has been accomplished in a relatively short time, which gives us hope that in a few years all employers and employees in the shoe industry will use the French technical terms when they are speaking French. 
Parity boards and apprenticeship commissions, just like governments, public authorities, liberal professions, and others, are not perfect. But if we consider the work they have accomplished in so short a time, and without serious reasons for criticism, there is no doubt they can withstand comparison with the most efficient and meritorious institutions.
Improving the technical language of a trade or profession is only a very small part of the task which falls to parity boards and apprenticeship commissions; but from my point of view this work is so important, so necessary, and so urgent, that if the boards and commissions had done nothing but that, they would already have proved their worth.

\title{
THE CONCEPT AND DEVELOPMENT OF LABOUR LAW
}

\author{
RenÉ H. MankIewicz
}

\section{Definition and scope}

Labour law can be defined as "the body of rules either deviating from, or supplementary to, the general rules of law, which regulate the rights and duties of persons performing or accepting the work of a subordinate". The validity of the labour contract is of no importance for the application of these rules to a given case. The rights and obligations of the persons concerned result directly from the performance or acceptance of labour under the direction of somebody else. Thus it has been admitted by certain courts that the employee has to be paid the wages established by a collective agreement or similar regulations even if the labour contract is void, e.g., when a minor hires out his services without having the capacity to do so. Likewise, according to certain national laws the absence of a valid contract does not affect the rights which the employee may have in regard to social insurance benefits, etc.

The difference between an "employee" in the meaning of labour law and any other individual who is working for, or giving services to, another person lies in his state of "dependence" in regard to the employer. This dependence is to be understood in a purely material sense. It signifies a real subordination of the employee to the employer. It finds its most precise expression in the "right to direct" the employee, thus permitting the employer to tell him what kind of work to do, and to prescribe the working conditions, working hours, etc. of each particular job.

Nevertheless there are people who, while not subordinated to somebody else and in charge of their own job and its material organisation, find themselves however in a state of economic dependance vis-à-vis a principal. Such are home workers, hairdressers who rent their chairs, taxi drivers, etc. Labour law identifies them with employees precisely on account of their lack of economic independence and freedom of movement.

On the other hand, there are men who work for another person and who yet keep a high degree of autonomy and liberty of action, remaining masters of their work and of the use of their time. This is for instance the case of presidents, executive managers and other corporation heads. They are subordinated to the corporation, a legal person, represented by the shareholders or some other qualified body. However, since these assemblies and bodies cannot direct and supervise them at every moment, general directors, executive officers and other "statutory representatives" of a legal person normally have the role, not of employees, but of employers, exercising in the place of the legal person the rights and duties which labour law establishes for the latter. This rule is not without exceptions and their number and extent vary according to the status of the director and his position within the company, and also according to the national law involved. Highly interesting legal decisions on all these questions can be found in the twelve volumes of the International Survey of Legal Decisions on Labour Law published by the I.L.O. For the years 1925 to $1938 / 39$ this survey analyses and digests the most important cases on labour law decided by the Law Courts of England, France, Germany, Italy and the United States. One can only regret that the I.L.O. did not resume this publication after the war.

The rules of labour law as embodied in statutes, administrative regulations, legal decisions and collective agreements, are not always limited to the relations between the dependent employee and his employer. Since they create special rights and 